\title{
Transmission of Pineapple Mealybug Wilt-Associated Virus by Two Species of Mealybug (Dysmicoccus spp.)
}

\author{
D. M. Sether, D. E. Ullman, and J. S. Hu
}

First and third authors: Department of Plant Pathology, University of Hawaii, Honolulu 96822; and second author: Department of Entomology, University of California, Davis 95616.

Accepted for publication 4 August 1998.

\section{ABSTRACT}

Sether, D. M., Ullman, D. E., and Hu, J. S. 1998. Transmission of pineapple mealybug wilt-associated virus by two species of mealybug (Dysmicoccus spp.). Phytopathology 88:1224-1230.

Closterovirus-like particles associated with mealybug wilt of pineapple were acquired and transmitted by the pink pineapple mealybug, Dysmicoccus brevipes, and the gray pineapple mealybug, D. neobrevipes. Mealybugs acquired pineapple mealybug wilt-associated virus (PMWaV) from infected pineapple plants or detached leaves. The virus was detected in plants by tissue blot immunoassay and confirmed by immunosorbent electron microscopy. Plants exposed to mealybugs reared on PMWaV-free pineapple tissue remained uninfected. The presence of ants was correlated with an increased rate of virus spread when caged with $D$. brevipes. All stages of $D$. neobrevipes acquired PMWaV, although vector efficiency decreased significantly in older adult females. The probability of a single third-instar immature transmitting the virus was 0.04. Both species of mealybug acquired and transmitted PMWaV from infected pineapple material that had been clonally propagated for decades, and both species acquired PMWaV from sources previously infected with the virus by the other mealybug species.

Additional keywords: Pheidole megacephala, virus transmission.
Mealybug wilt of pineapple (MWP) is one of the most serious diseases of pineapple $(20,42)$ and occurs worldwide in all the major pineapple production areas (J. S. Hu and D. M. Sether, unpublished data). The etiology of the disease is unknown, although mealybugs and ants are known to be involved in the epidemiology $(4,8,14,27)$. Two species of mealybug, the pink pineapple mealybug, Dysmicoccus brevipes (Cockerell), and the gray pineapple mealybug, D. neobrevipes Beardsley, have been associated with MWP $(4,14)$. Several species of ants are associated with mealybugs $(4,14$, 39). The ants assist in the establishment of mealybug colonies (13, 14,42 ), consuming the honeydew produced by the mealybugs (37), and can have a suppressive effect on the mealybugs' natural enemies $(16,29)$. Efforts to control the spread of MWP are often directed at control of the ants. An early hypothesis for the cause of MWP suggested that toxins present in the salivary secretions of mealybugs were responsible for the symptoms of this disorder $(8,10)$. However, it was later noted that symptoms rarely appeared if mealybugs were fed on healthy seedling plants prior to being transferred to test plants (11). Furthermore, symptoms frequently appeared if mealybugs were fed on positive source plants prior to being transferred to test plants (12). These data led to a modified hypothesis that suggested the involvement of a latent transmissible factor in the disease (14).

Nearly a decade ago, flexuous closterovirus-like particles were isolated from pineapple plants expressing MWP symptoms (22-24). Such particles were repeatedly isolated from plants in Hawaii and Australia $(22,25,26,47,48)$ and have been detected in samples worldwide (J. S. Hu and D. M. Sether, unpublished data). Undoubtedly, clonal propagation of infected pineapple material through crowns and slips, which has continued for decades, has contributed to the prevalence of this virus in pineapple throughout the world. The

Corresponding author: J. S. Hu; E-mail address: johnhu@hawaii.edu

Publication no. P-1998-0925-01R

(C) 1998 The American Phytopathological Society involvement of the closterovirus-like particles in the development of mealybug wilt remains unclear. This virus has formerly been referred to in the literature as pineapple closterovirus $(25,26)$. Because of the observed association between disease symptoms and mealybugs (25; D. M. Sether and J. S. Hu, unpublished data), pineapple mealybug wilt-associated virus (PMWaV) has been proposed as the name for this virus, following the convention used for grape leafroll-associated closteroviruses (1). The physical characteristics of this nonmechanically transmissible virus tentatively place it in the monopartite genus in the family Closteroviridae (1).

A major factor hindering PMWaV transmission work has been the lack of a rapid and reliable detection assay. Symptomology alone is insufficient for determining the absence of PMWaV, because pineapple plants can host the virus without expressing wilt symptoms $(25,26,47,48)$. In addition, symptom expression is also variable and apparently linked to factors such as environmental conditions, mealybug populations, and pineapple genotype $(11,15)$. Recently, monoclonal antibodies were produced against a Hawaiian PMWaV isolate (26). Utilizing these antibodies in tissue blot immunoassays (TBIA) and immunosorbent electron microscopy (ISEM) provides a means of determining the PMWaV status of plant material (25). The ability to distinguish infected and uninfected plants enables the evaluation of mealybug acquisition and transmission characteristics of PMWaV. Although previous evidence supports the association between mealybugs, PMWaV, and MWP (26; D. M. Sether and J. S. Hu, unpublished data), mealybugs have not yet been proven to transmit PMWaV between pineapple plants. The experiments described here were designed to test the competence and efficiency of $D$. brevipes and $D$. neobrevipes as vectors of PMWaV in pineapple. A preliminary abstract of this work has been published (45).

\section{MATERIALS AND METHODS}

Mealybug colonies. $D$. brevipes mealybugs were obtained from the University of Hawaii, Department of Entomology, and maintained on the fruit of butternut squash (Cucurbita moschata (Duchesne) Duchesne ex Poir.). All D. brevipes used in these experi- 
ments were females, because males are not present in Hawaii (3). D. neobrevipes mealybugs were collected from Agave sp. and maintained in a separate facility on agave and the fruit of Danish (C. pepo L.) and kobacha (C. maxima Duchesne) squash. Both sexes of $D$. neobrevipes are present in Hawaii, and both were used in these experiments. Voucher specimens of the two colonies were cleared and mounted following published procedures (50). Identifications were made following published keys $(2,49)$.

Plant material. Crowns, the vegetative propagules on top of pineapple fruits (30), were collected from a plantation-grown selection of Ananas comosus (L.) Merr. cv. Smooth Cayenne and rooted under insect-free conditions. Crown-derived plants were approximately 5 months old at the time of $D$. brevipes introduction. Pineapple plants were also started from seed and multiplied through tissue culture (52). Seed-derived plants were established in soil 1 or 3 months prior to $D$. neobrevipes and $D$. brevipes introductions, respectively. TBIA (25) was used a minimum of three times over several months to establish the PMWaV status of each plant prior to mealybug exposure. The PMWaV status of each plant remained unchanged for the period preceding mealybug introduction. PMWaV source plants for initial $D$. brevipes experiments were established from PMWaV-infected crowns collected from a commercial plantation in Hawaii (26). Source plants for later work were seed-derived or PMWaV-free crown-derived plants infected with PMWaV by $D$. brevipes or $D$. neobrevipes.

Tissue blot immunoassay. TBIA for PMWaV was used in conjunction with ISEM for virus assays. A single leaf from the upper one-third of the stem or crown was pulled out and assayed for PMWaV by TBIA as previously described (25). Briefly, a freshly collected leaf was cut transversely with a razor blade across the white portion at the base of the leaf. The cut edge was pressed onto nitrocellulose membrane, Nitro ME (Micron Separations, Inc., Westboro, MA), and incubated with PMWaV-specific monoclonal antibody 35-6-5 (1 $\mu \mathrm{g} / \mathrm{ml})(26)$ and goat anti-mouse alkaline phosphatase-conjugated antibody (1:1,000 dilution) (\#A5158; Sigma Chemical Co., St. Louis) in Tris-buffered saline $(50 \mathrm{mM}$ Tris- $\mathrm{HCl}, \mathrm{pH} 7.5$, and $50 \mathrm{mM} \mathrm{NaCl}$ ). Membranes were developed in 5-bromo-4-chloro-3-indolyl phosphate/nitro blue tetrazolium (\#5655; Sigma Chemical Co.), vacuum-dried, and assessed with the aid of a dissecting microscope. When using TBIA on very young seed-derived test plants, leaves with actively feeding mealybugs and with enough rigidity to be blotted were selected for virus detection. The leaf was rolled longitudinally, cut transversely, and blotted on membranes as described above. Sequential cuts and blots were made up the leaf at approximately 6-mm intervals.

Electron microscopy. ISEM and negative-stain transmission electron microscopy were used on crude and gradient-purified preparations made from arbitrarily selected plants as previously described (26). Formvar-coated, carbon-stabilized grids (Ted Pella, Inc., Redding, CA) were stained with an aqueous solution saturated with uranyl acetate (Ted Pella, Inc.) and observed using a Zeiss 10A transmission electron microscope (Carl Zeiss, Inc.; Oberkochen, Germany).

Experimental conditions for $\boldsymbol{D}$. brevipes transmission. Mesh cages, $1 \times 1.5 \times 1 \mathrm{~m}$ (length $\times$ width $\times$ height), were constructed to contain all stages of $D$. brevipes and exclude other arthropods. Cage legs were set in water traps, and Amdro granular insecticide (American Cyanamid Co., Wayne, NJ) was used around the cages for ant control when necessary. Cages were enclosed in a ventilated, white-washed greenhouse where temperatures ranged from 21 to $32^{\circ} \mathrm{C}$. Each treatment was carried out in a separate cage, and the experiment was performed twice without ants and twice with the addition of ants. Three treatments were used. These consisted of (i) crown-derived plants with and without PMWaV that were maintained mealybug free for the duration of the experiment; (ii) PMWaV-free, crown- and seed-derived plants; and (iii) PMWaVinfected crown-derived plants placed randomly among PMWaV-free crown- and seed-derived plants. The same pattern of plant placement was used for all replicates for treatment set 3. Approxi- mately 3,000 to 4,000 D. brevipes immatures and 50 to 100 adults reared on squash were initially introduced to cages containing treatments 2 and 3 . In the case of treatment 3,D. brevipes was added only to PMWaV-positive plants and allowed to move to PMWaVfree plants naturally. All plants within a cage were in direct contact with adjacent plants. Ants (Pheidole megacephala (Fabricius)) used in the later two trials were introduced by placing a colony established in a 1-gallon pot containing a PMWaV-free, seedderived pineapple plant inside the cages of treatment 3. Due to availability, the PMWaV-free plants used in ant experiments were all seed derived.

Experimental conditions for $D$. neobrevipes transmission. PMWaV source plants were either directly from commercial plantations or crown- or seed-derived plants previously infected with PMWaV by $D$. brevipes. PMWaV-free plants were either crownor seed-derived plants with no previous mealybug exposure. The white portions at the basal end of PMWaV-free leaves were placed in deep petri dishes lined with \#1 filter paper (Whatman, Hillsboro, OR), and gravid $D$. neobrevipes females were added. Nymphs produced were gently transferred with a camel hair brush every 3 days to new petri dishes with either PMWaV-free or -infected detached leaves. Infected leaves were changed every 2 to 4 days. Mealybugs used for acquisition studies were only given an acquisition access period (AAP) to PMWaV-infected leaf material during the instar or age period being tested. The age groups used were firstand second-instar immatures of both sexes, third-instar immature females, newly gravid adult females, older gravid females (over 20 days into the larvapositional period), and post-larvapositional females no longer producing offspring. The AAP lasted 5 to 7 days before mealybugs were transferred, in groups of 20 , to PMWaVfree seed-derived plants for the inoculation access period (IAP). Groups of 1, 5, 10, 20, and 40 third-instar immatures reared on either PMWaV-free or -infected leaf material were transferred to young seed-derived pineapple plants for vector efficiency studies.

A detached leaf method was also used for testing the ability of both species to acquire and transmit from plants infected with PMWaV by the other mealybug species. Prior to the AAP, PMWaVinfected leaves were wiped clean to insure against cross-contamination of species. Squash-reared $D$. neobrevipes immatures were placed on clean, detached infected leaves from previous $D$. brevipes transmission trials, and $D$. brevipes were placed on PMWaV leaves infected by $D$. neobrevipes. Immatures were transferred after 4 days to PMWaV-free seed-derived plants for the IAP.

$D$. brevipes and $D$. neobrevipes experiments were performed in separate facilities. Transmission experiments comparing acquisition ability of the different age classes of $D$. neobrevipes were replicated four times with five plants for each replicate, except for those with post-larvapositional females, which were only replicated three times. Experiments with varying numbers of third-instar immatures were repeated three times with 15 plants for single immatures and 5 plants for all other groups. Plants were kept separated and placed in individual water traps to avoid cross-contamination by $D$. neobrevipes immatures from other plants. The threat of crosscontamination by mobile winged males was disregarded because of their lack of externally developed mouthparts (27). D. neobrevipes mealybugs fed on PMWaV-free leaves were included as negative checks in all trials. Test plants were subjected to TBIA as early as 20 days following the IAP and at various subsequent intervals. ISEM and negative-stain electron microscopy were used to confirm TBIA results in arbitrarily selected plants.

Statistical analysis of $\boldsymbol{D}$. brevipes experiments. The independent (time) and dependent (percentage of disease) variables from each replicate within the two experiments with and without ants were fit to linear regression models, forcing the origin through zero. A $95 \%$ confidence interval was calculated for the difference between slopes of the two replicates within each experiment (7). If the confidence interval included zero, then the replicates were treated as if they were estimating the same population and pooled. Pooled 
replicates for each treatment were fit to linear, exponential, logistic, Gompertz, and monomolecular models (7) using SAS general linear model (GLM) analysis (SAS Institute, Cary, NC). The independent variable was (percentage of disease +0.1 ) $/ 100$. Goodnessof-fit was evaluated by visual assessment of the residual plots, back-transformed $R^{2}$ values, and mean square for errors. The two population regression coefficients for slope were tested for equality with a one-tailed test using Student's $t$ test. The hypotheses were $\mathrm{H}_{0}=\beta_{1} \leq \beta_{2}$; and $\mathrm{H}_{\mathrm{a}}=\beta_{1}>\beta_{2}$, rejecting $\mathrm{H}_{0}$ if $t \geq t_{\alpha=0.05,18 \mathrm{df}}$, in which $\beta_{1}$ and $\beta_{2}$ are the slopes of regression lines with and without ants, respectively (51). Confidence intervals (95\%) were calculated for the two regression lines representing pooled replicates (7).

Statistical analysis of $D$. neobrevipes experiments. The abilities of different age groups to acquire and transmit PMWaV were compared with one-tailed Mann-Whitney tests for tied ranks $(\alpha=$ $0.05)$ (17). Measurements used for comparison were the proportion of infected plants in each replicate within a treatment. The treatments, each containing four measurements, were compared only with treatments from the same sampling period. The transmission experiments using different numbers of immature treatments were compared in a similar manner, but had three measurements per treatment. Probability of transmission by a single insect $(p)$ was estimated using $p=1-(1-I)^{1 / k}$, in which $I$ was the proportion of positive plants detected with TBIA and $k$ was the number of insects tested per plant (46).

\section{RESULTS}

Transmission by $D$. brevipes. Pink pineapple mealybugs (D. brevipes) reared on squash acquired PMWaV from infected crownderived pineapple plants and transmitted the virus to previously
PMWaV-free plants, where it was detected by TBIA (Tables 1 and 2) and ISEM (Fig. 1). When PMWaV-free plants were caged with D. brevipes-infested PMWaV-infected plants with no ants present, PMWaV was detected in $100 \%$ of the crown- and seed-derived plants after 150 days (third sampling date) and 220 days (fifth sampling date), respectively (Table 1). When ants were present, PMWaV was detected in $100 \%$ of the seed-derived plants after 175 days (fourth sampling date) (Table 2). All plants in treatments 1 (closterovirus-free plants with no mealybugs) and 2 (closterovirusfree plants with mealybugs from squash) remained PMWaV-free for the duration of the transmission experiments. The simple linear equations for the two replicates without ants were $Y=0.456 x\left(R^{2}=\right.$ $0.993)$ and $Y=0.498 x\left(R^{2}=0.969\right)$ and with ants were $Y=0.594 x$ $\left(R^{2}=0.948\right)$ and $Y=0.634 x\left(R^{2}=0.940\right)$. Based on $95 \%$ confidence intervals for pairs of replicates within the two experiments with and without ants, the replicates were estimating the same population and were pooled for further analyses. Simple linear regression models provided the best fit for the two experiments with and without ants (Table 3 ). The simple linear regression equations derived using pooled replicates were $Y=0.478 x$ for PMWaV spread in the absence of ants and $Y=0.615 x$ for virus spread in the presence of ants (Fig. 2). Comparison of the confidence intervals for the two regression lines for ants and no ants indicated that the lines were different $(P<0.0001)$. A one-tailed test for equality of the two population regression coefficients for slope resulted in a $t$ value of 4.16 with $18 \mathrm{df}(P<0.0005)$, supporting rejection of the null hypotheses $\left(\mathrm{H}_{0}\right)\left(\beta_{1} \leq \beta_{2}\right)$ in favor of $\mathrm{H}_{\mathrm{a}}=\beta_{1}>\beta_{2}$ and allowing the conclusion that ants had a positive effect on virus spread.

Transmission by $D$. neobrevipes. Gray pineapple mealybugs (D. neobrevipes) are also competent vectors of PMWaV (Table 4). Immatures and gravid females were able to acquire and transmit the

TABLE 1. Transmission of pineapple mealybug wilt-associated virus (PMWaV) by the pink pineapple mealybug, Dysmicoccus brevipes, to pineapple plants in the absence of ants

\begin{tabular}{|c|c|c|c|c|c|c|}
\hline \multirow[b]{2}{*}{ Treatments } & \multicolumn{6}{|c|}{ Days after initial mealybug introduction ${ }^{y}$} \\
\hline & 0 & 50 & 100 & 150 & 186 & 220 \\
\hline \multicolumn{7}{|l|}{ No mealybugs } \\
\hline Crown-derived plants & $0 / 8$ & $0 / 8$ & $0 / 8$ & $0 / 8$ & $0 / 8$ & $0 / 8$ \\
\hline PMWaV-infected plants & $20 / 20$ & $20 / 20$ & $20 / 20$ & $20 / 20$ & $20 / 20$ & $20 / 20$ \\
\hline \multicolumn{7}{|l|}{ PMWaV-free mealybugs } \\
\hline Crown-derived plants & $0 / 8$ & $0 / 8$ & $0 / 8$ & $0 / 8$ & $0 / 8$ & $0 / 8$ \\
\hline \multicolumn{7}{|l|}{ PMWaV-free mealybugs } \\
\hline Crown-derived plants & $0 / 8$ & $6 / 8$ & $7 / 8$ & $8 / 8$ & $8 / 8$ & $8 / 8$ \\
\hline Seed-derived plants & $0 / 20$ & $6 / 20$ & $10 / 20$ & $16 / 20$ & $18 / 20$ & $20 / 20$ \\
\hline PMWaV-infected source plants ${ }^{\mathrm{z}}$ & $18 / 18$ & $18 / 18$ & $18 / 18$ & $18 / 18$ & $18 / 18$ & $18 / 18$ \\
\hline
\end{tabular}

y Number of PMWaV-infected plants/total number of plants exposed. PMWaV was detected by tissue blot immunoassay and confirmed in arbitrarily selected plants with immunosorbent electron microscopy. All plants exposed to D. brevipes reared on PMWaV-free pineapple remained PMWaV free. Numbers reflect two combined replicates.

${ }^{\text {z }}$ Eighteen PMWaV-infected plants were inoculated with 3,000 to 4,000 D. brevipes and placed among the PMWaV-free plants.

TABLE 2. Transmission of pineapple mealybug wilt-associated virus (PMWaV) by the pink pineapple mealybug, Dysmicoccus brevipes, to pineapple plants in the presence of ants

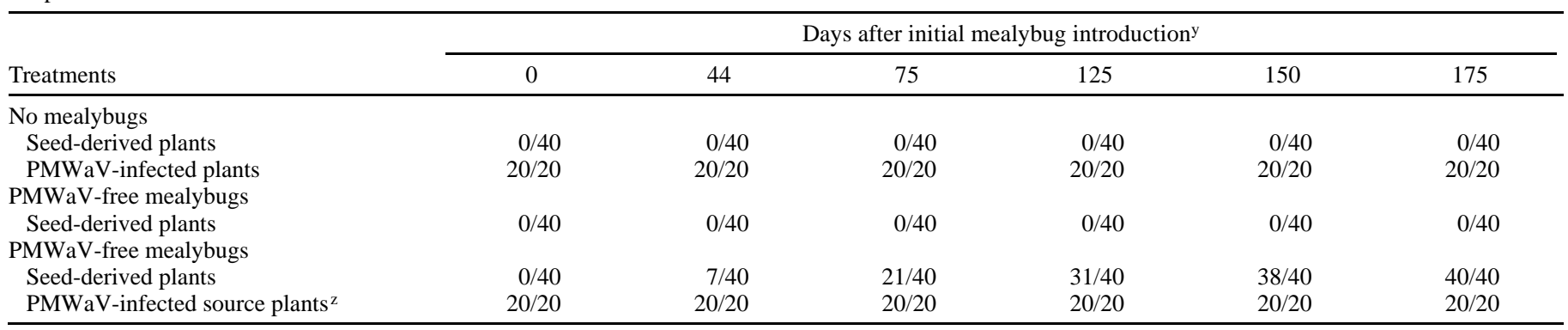

y Number of PMWaV-infected plants/total number of plants exposed. PMWaV was detected by tissue blot immunoassay and confirmed in arbitrarily selected

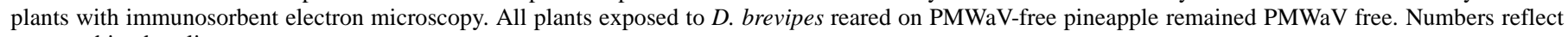
two combined replicates.

z Twenty infected plants were inoculated with 3,000 to 4,000 D. brevipes and placed among the PMWaV-free plants. 
virus. Second- and third-instar immatures were significantly more efficient vectors than first instars and gravid females $(0.025 \leq P<$ $0.05)$. Third-instar immatures were marginally more efficient than second instars $(0.05<P<0.10)$. Gravid females given an AAP less then 20 days after molting were significantly more efficient vectors than gravid females given an AAP 20 days after molting $(0.025 \leq P<0.05)$. Test plants exposed to post-larvapositional females did not develop any PMWaV infections. No mealybugs transmitted PMWaV when fed only on virus-free leaves.

Exposure to groups of 10, 20, and 40 viruliferous third-instar immatures resulted in significantly more infections than either single or groups of five viruliferous immatures $(0.05 \leq P)$ (Table 5). Viruliferous immatures were reared on PMWaV-infected detached leaves beginning from the first instar. PMWaV infections were detected in $100 \%$ of the plants 75 days after being infested with 20 viruliferous immatures. Eight PMWaV infections were detected 20 days after the IAP, although the majority of infections were detected after 30 days or more. Using the actual transmission rate observed for groups of five third instars, the estimated probability $(P)$ of

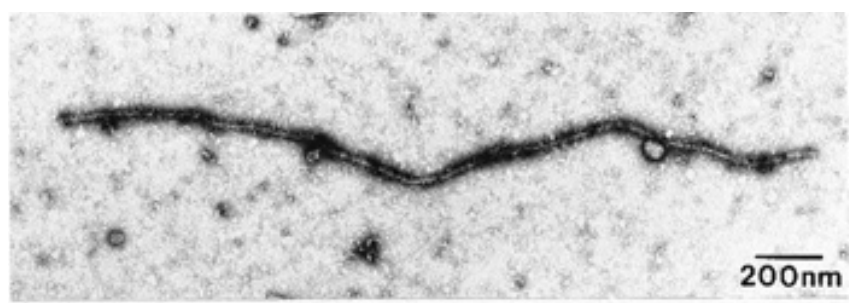

Fig. 1. Immunosorbent electron microscopy detection of a pineapple mealybug wilt-associated virus (PMWaV)-like particle transmitted to a seed-derived pineapple plant by viruliferous mealybugs. Decoration is with Hawaiian PMWaV monoclonal antibody 35-6-5 and goat anti-mouse immunoglobulin $\mathrm{G}$ conjugated to $10 \mathrm{~nm}$ of gold particles. No particles were found in samples from seedling plants exposed to nonviruliferous mealybugs. transmission by a single insect was 0.043 . The actual observed proportion of infected plants after exposure to a single third-instar mealybug was $0.044(2 / 45)$. When the probability of transmission was calculated using groups of 10,20 , or 40 immatures, estimates were $0.085,1.000$, and 1.000 , respectively.

Virus detection and acquisition from sources infected by the other mealybug species. In many cases, the initial virus infection was detected only in single or a few major vascular bundles of a single leaf (Fig. 3A). Closterovirus infection of a single vascular

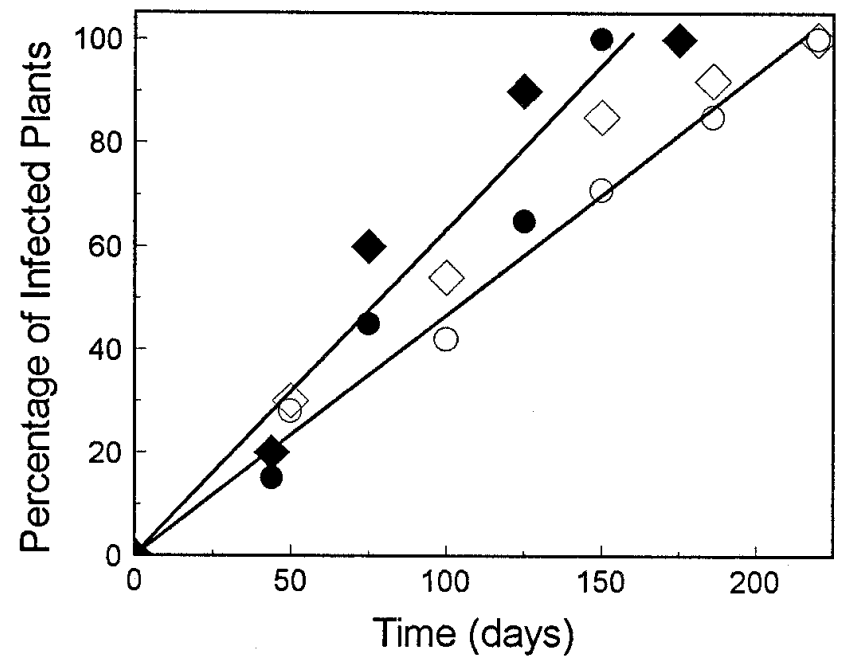

Fig. 2. Spread of pineapple mealybug wilt-associated virus by Dysmicoccus brevipes with and without the presence of ants. Simple linear regression lines are fit to the groups: ants $(\bullet=$ replicate $1 ; \bullet=$ replicate 2$)$ and no ants $(O=$ replicate $1 ; \diamond=$ replicate 2 ). Equations for the regression lines using pooled replicates are $Y=0.615 x$ in the presence of ants and $Y=0.478 x$ in the absence of ants.

TABLE 3. Summary statistics of the linear regression analyses results used to evaluate five models for appropriateness in describing transmission (\%) of pineapple mealybug wilt-associated virus (PMWaV) by Dysmicoccus brevipes with and without ants present ${ }^{\mathrm{y}}$

\begin{tabular}{|c|c|c|c|c|c|c|}
\hline Model & $R^{2}$ & $R^{* 2}$ & MSE & Rate & SE & Residual plot \\
\hline \multicolumn{7}{|l|}{ Ants present } \\
\hline Simple & 0.942 & 0.942 & 1.010 & 0.615 & 3.021 & Random; $-0.12-0.15$ \\
\hline Exponential & 0.660 & 0.494 & 250.927 & 3.718 & 0.872 & Pattern; $-1.8-2.0$ \\
\hline Gompertz ${ }^{\mathrm{z}}$ & 0.914 & 0.954 & 45.331 & 2.801 & 0.358 & Pattern; $-1.0-0.6$ \\
\hline Monomolecular ${ }^{2}$ & 0.747 & 0.854 & 17.940 & 1.382 & 0.324 & Random; $-0.5-1.6$ \\
\hline \multicolumn{7}{|l|}{ Ants absent } \\
\hline Simple & 0.977 & 0.977 & 5.840 & 0.478 & 0.022 & Random; $-0.8-0.12$ \\
\hline Gompertz $^{z}$ & 0.948 & 0.961 & 13.461 & 2.089 & 0.173 & Random; $-0.4-0.5$ \\
\hline Monomolecular ${ }^{\mathrm{Z}}$ & 0.883 & 0.910 & 10.437 & 1.192 & 0.153 & Random; $-0.5-0.5$ \\
\hline
\end{tabular}

${ }^{\text {y }} R^{2}=$ correlation coefficient; $R^{* 2}=$ correlation coefficient after back transformation; MSE = mean square for error $\times 100$; rate $=$ slope parameter $\times 100$; SE $=$ standard error of slope parameter $\times 100$; residual plot $=$ scattering of residuals; range of residuals.

${ }^{\mathrm{z}}$ Values equal to zero were entered as 0.100 for logistic and Gompertz models; proportions were used for the monomolecular model.

TABLE 4. The effects of age during the acquisition access period (AAP) on the ability of Dysmicoccus neobrevipes to transmit pineapple mealybug wilt-associated virus (PMWaV) to PMWaV-free pineapple seedlings

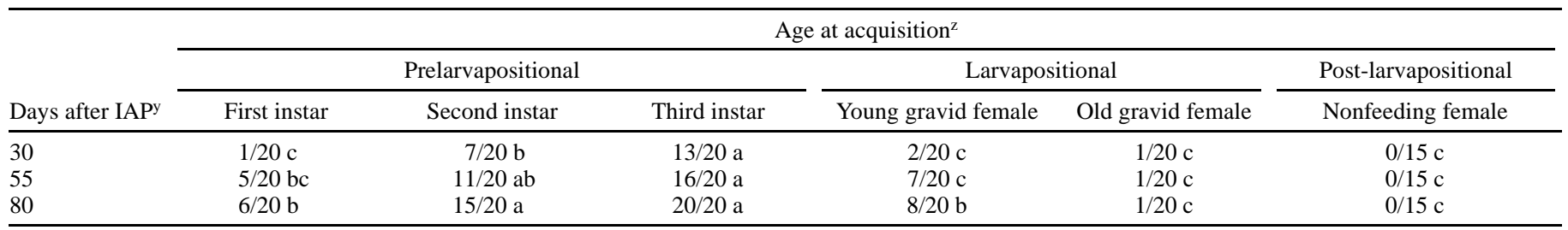

y Inoculation access period.

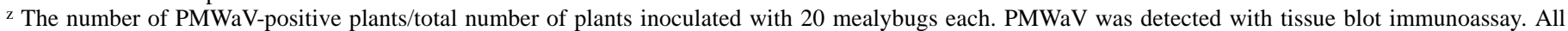
plants exposed to D. neobrevipes reared on PMWaV-free pineapple remained PMWaV free. Values within rows labeled with different letters are significantly different $(P \leq 0.05)$ according to Mann-Whitney tests for tied ranks. Numbers reflect four combined replicates except in the case of nonfeeding females, which is three combined replicates. 
bundle could be detected from the point of leaf attachment to within $2 \mathrm{~cm}$ of the leaf tip, but was not detected in other vascular elements of the same leaf. Generally, virus could be detected in most major and some minor vascular bundles of plants infected with PMWaV for more than 60 days (Fig. 3B).

Nonviruliferous $D$. brevipes mealybugs acquired and transmitted PMWaV from detached leaves or entire plants previously infected with PMWaV by $D$. neobrevipes. Likewise, $D$. neobrevipes mealybugs were able to acquire and transmit PMWaV from plants infected with PMWaV by $D$. brevipes (data not shown).

Detached pineapple leaves with PMWaV present in major vascular bundles were suitable for acquisition access feeding for at least 3 days. Virus could be consistently detected in infected detached leaves that were used for the AAP for 3 to 15 days after detachment (data not shown). Seed-derived plants with no previous exposure to mealybugs were always $100 \% \mathrm{PMWaV}$ free.

\section{DISCUSSION}

We have demonstrated that both the pink pineapple mealybug (D. brevipes) and the gray pineapple mealybug (D. neobrevipes) can acquire and transmit PMWaV. Mealybugs are also known vectors of other plant viruses including the closteroviruses grapevine leafroll-associated virus 3 (GLRaV-3) $(6,18,38)$, little cherry virus (40), and sugarcane mild mosaic virus $(32,33)$; the trichoviruses grapevine virus A and B (GVA and GVB, respectively) (19,31,43, 44); and an expanding list of badnaviruses (33-35).

PMWaV can be spread by $D$. brevipes in the presence or absence of ants, but a higher rate of spread is associated with the presence of ants (Fig. 2). The reason for this is unknown. The ants consume the honeydew of the mealybugs, which reduces the occurrence of sooty mold associated with the honeydew $(9,37)$. It is possible that the presence of the ants improves the population growth rate or survival of the mealybugs. Another possibility is that the presence of the ants modifies the behavior of the mealybugs, resulting in a faster rate of plant colonization. It should be noted that the number and type of plant material included in the cages in the experiments with and without ants were different (Tables 1 and 2); there were more seed-derived plants in the cages with ants. The effect of this, if any, is unknown. The ratio of virus source plants to healthy plants in experiments with ants was 1:2 (0.50) and without ants was 9:14 (0.64). If the rate of spread was positively biased by the proportion of infected plants, then the estimated rate of spread in the absence of ants would be greater than that observed. Instead, the rate of spread in the presence of ants was significantly greater even in the presence of such possible bias. Ants also have an impact on mealybug populations in the fields of commercial pineapple plantations around the world $(39,41)$. Control of mealybugs and the associated MWP is largely achieved by controlling the ants $(4,13,42)$.

TABLE 5. Transmission of pineapple mealybug wilt-associated virus (PMWaV) to pineapple seedlings by Dysmicoccus neobrevipes third-instar nymphs reared on PMWaV-infected detached leaves from the first instar

\begin{tabular}{lccccc}
\hline & \multicolumn{5}{c}{ Number of immatures $^{\mathrm{x}}$} \\
\cline { 2 - 6 } Days after IAP $^{\mathrm{w}}$ & 1 & 5 & 10 & 20 & 40 \\
\hline 20 & $0 / 45 \mathrm{~b}$ & $0 / 15 \mathrm{~b}$ & $1 / 15 \mathrm{~b}$ & $2 / 15 \mathrm{~b}$ & $5 / 15 \mathrm{a}$ \\
30 & $0 / 45 \mathrm{~b}$ & $1 / 15 \mathrm{~b}$ & $6 / 14^{\mathrm{y}} \mathrm{a}$ & $7 / 15 \mathrm{a}$ & $8 / 15 \mathrm{a}$ \\
50 & $1 / 45 \mathrm{c}$ & $3 / 15 \mathrm{~b}$ & $10 / 14 \mathrm{a}$ & $14 / 15 \mathrm{a}$ & $13 / 15 \mathrm{a}$ \\
75 & $2 / 45 \mathrm{~b}$ & $3 / 15 \mathrm{~b}$ & $10 / 14 \mathrm{a}$ & $15 / 15 \mathrm{a}$ & $14^{\mathrm{z}} / 15 \mathrm{a}$ \\
\hline
\end{tabular}

${ }^{\mathrm{w}}$ Inoculation access period.

x Number of PMWaV-infected plants/total number of plants exposed. Values within rows labeled with different letters are significantly different $(P \leq$ 0.05 ) according to Mann-Whitney tests for tied ranks. Numbers reflect three combined replicates. All plants exposed to D. neobrevipes reared on PMWaV-free pineapple remained PMWaV free.

y One plant was killed during previous sampling.

z $15 / 15$ after 85 days.
These results demonstrate that second and third instars of $D$. neobrevipes are more efficient at acquiring PMWaV than first instars and gravid females (Table 4). Pseudococcus longispinus (Targioni-Tozzetti) mealybugs are also more efficient vectors of GVA than Pseudococcus longispinus adults (44). Because the mealybugs were allowed to feed for the entire duration of the transmission portion of the experiment, it could not be ascertained whether or not particular developmental instars or stages were more efficient at transmitting the virus. The retention time for GLRaV-3, another mealybug-transmitted virus, in the vector Planococcus citri is approximately $24 \mathrm{~h}$ (6). If the retention times for PMWaV in its mealybug vectors are similar, then the results in Table 4 would also represent relative vector efficiencies at different developmental periods. Additionally, viruses such as GLRaV that are transmitted in a semipersistent manner are not generally retained through molts (21), further suggesting that the observed results (Table 4) reflect virus transmission efficiencies of the different stages. Only $5 \%$ of the plants exposed to the older gravid females (AAP 20 days after molting) developed infections (Table 4). This lack of efficient transmission by older gravid females could have been due to cessation of feeding during the IAP. These older gravid females had their stylets inserted into the acquisition source leaves before they were transferred for the IAP. It is possible that the feeding interruption caused by the transfer at this stage interferes with future feeding during the IAP. Post-larvapositional females did not transmit PMWaV. We observed that mealybugs in this age group did not have their stylets inserted in the acquisition source leaves immediately before being transferred, and it has been noted previously that this age group does not normally feed (28).

Exposure of each of the test plants to 20 older gravid D. neobrevipes females resulted in only 1 out of $20(5 \%)$ plants developing a PMWaV infection, even though many immatures were produced and fed on the same test plant. If PMWaV were transovarially transmitted to these immatures, the infection rates should have been much higher because of the greater number of vectors present. Since this was not found to be the case, it is likely that PMWaV is not transovarially transmitted in $D$. neobrevipes.

The calculated probability of transmission using groups of five immatures (0.043) equals the actual observed infection rate $(4 \%)$ (Table 5) with single $D$. neobrevipes immatures. The transmission probability estimated and demonstrated for PMWaV by $D$. neobrevipes is similar to the previous estimate of 0.02 for GLRaV-3 by Planococcus citri (6), the 0.01 to 0.03 estimated for GLRaV by Pseudococcus calceolariae (38), and the 0.03 to 0.08 estimated for GLRaV-3 by Pseudococcus longispinus (38). The probability of PMWaV transmission using larger groups of insects $(k=10$,

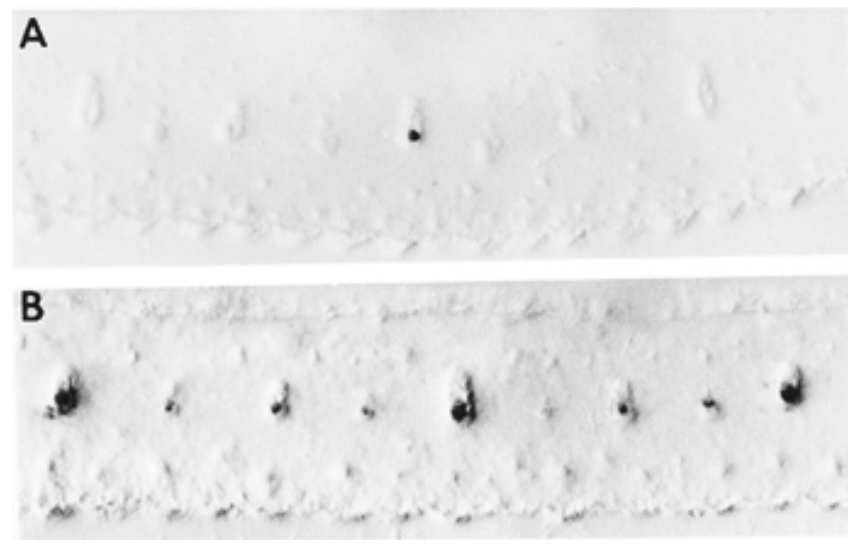

Fig. 3. Detection of pineapple mealybug wilt-associated virus (PMWaV) in vascular bundles of infected leaves using direct tissue blotting assay. A, Detection of PMWaV in a single vascular bundle of a pineapple leaf 20 days after the leaf was exposed to viruliferous mealybugs. B, Detection of PMWaV in most major and minor vascular bundles of a new pineapple leaf 60 days after older leaves were exposed to viruliferous mealybugs. 
20 , or 40) resulted in predicted efficiencies of $0.085,1.000$, and 1.000 , respectively. Higher probabilities, 0.07 to 0.11 , were estimated for transmission of GLRaV by Pseudococcus calceolariae when 20 to 30 vectors were used (6). Statistical bias is expected when $k>5$, because of increasing mean square errors $(5,7,46)$. However, the difference between the calculated probability using 10 immatures per plant (0.085) and actual transmission results using single immatures (0.04) could also suggest a behavioral or virus dosage effect when larger numbers of vectors are used. The predicted probabilities using 10 immatures may be a reflection of such behavioral or dosage threshold phenomenon when multiple vectors are present on the same plant.

TBIA results showed that PMWaV infection was initially limited to a few vascular bundles. Presumably, these were the bundles that had initially been fed on by viruliferous mealybugs. Once PMWaV was introduced into the phloem by mealybug feeding, it moved systemically to the major, and often the minor, vascular bundles of other leaves. PMWaV was never detected in tissue outside the vascular bundles. This apparent phloem limitation is characteristic of closteroviruses (36).

Virus could still be detected in detached pineapple leaves up to 15 days after removal from plants. This raises the possibility that rogued, infected plants left in the immediate proximity of pineapple fields may act as PMWaV reservoirs. The presence of numerous grasses and weeds that play host to mealybugs in or near pineapple fields could act as PMWaV reservoirs if they are found to be virus hosts. Screening and transmission studies to identify alternate or propagative hosts of PMWaV are currently underway.

The use of mealybugs to transmit PMWaV provides a tool for evaluating the role of PMWaV in MWP. Representatives of pineapple species and cultivars from the Agriculture Research Service-National Clonal Germplasm Repository previously found to be PMWaV free (25) are currently being challenged with PMWaV viruliferous mealybugs in an effort to find PMWaV-resistant germ plasm. Insect transmission of PMWaV will also be used to evaluate transgenic pineapple plants engineered for resistance to PMWaV infection.

\section{ACKNOWLEDGMENTS}

This work was supported, in part, by a grant from the State of Hawaii Governor's Agricultural Coordinating Committee (contract no. 87-12) and by the Specific Cooperative Grant agreement 58-5320-5-604 between the USDA-ARS and the University of Hawaii. This is Journal Series 4354 of the Hawaii Institute of Tropical Agriculture and Human Resources. We thank C. Oda and V. Tyrell of Del Monte Fresh Produce (Hawaii) Inc., M. McClean at Dole Fresh Fruit Co., and H. Fleisch of Maui Land and Pine, Ltd. for providing pineapple plants; and W. Borth, M. Johnson, K. Rohrbach, and S. Nelson for their suggestions on preparation of this manuscript, statistical analysis, and epidemiological modeling.

\section{LITERATURE CITED}

1. Agranovsky, A. A. 1996. Principles of molecular organization, expression, and evolution of closteroviruses: Over the barriers. Adv. Virus Res. 47:119-158.

2. Beardsley, J. W. 1959. On the taxonomy of pineapple mealybugs in Hawaii, with a description of a previously unnamed species (Homoptera: Pseudococcidae). Proc. Hawaii. Entomol. Soc. 17:29-37.

3. Beardsley, J. W. 1965. Notes on the pineapple mealybug complex, with descriptions of two new species (Homoptera: Pseudococcidae). Hawaii Agric. Exp. Stn. Tech. Paper 728:55-68.

4. Beardsley, Jr., J. W., Su, T. H., McEwen, F. L., and Gerling, D. 1982. Field investigations on the interrelationships of the big-headed ant, the gray mealybug, and pineapple wilt disease in Hawaii. Proc. Hawaii. Entomol. Soc. 24:51-67.

5. Burrows, P. M. 1987. Improved estimation of pathogen transmission rates by group testing. Phytopathology 77:363-365.

6. Cabaleiro, C., and Segura, A. 1997. Field transmission of grapevine leafroll associated virus $3(\mathrm{GLRaV}-3)$ by the mealybug Planococcus citri. Plant Dis. 81:283-287.

7. Campbell, C. L., and Madden, L. V. 1990. Introduction to Plant Disease
Epidemiology. John Wiley \& Sons, New York.

8. Carter, W. 1933. The pineapple mealy bug, Pseudococcus brevipes, and wilt of pineapples. Phytopathology 23:207-242.

9. Carter, W. 1935. Studies on the biological control of Pseudococcus brevipes (Ckl.) in Jamaica and Central America. J. Econ. Entomol. 28:1037-1041.

10. Carter, W. 1939. Injuries to plants caused by insect toxins. Bot. Rev. 5: 273-326.

11. Carter, W. 1945. Some etiological aspects of mealybug wilt. Phytopathology 35:305-315.

12. Carter, W. 1951. The feeding sequence of Pseudococcus brevipes (Ckl) in relation to mealybug wilt of pineapples in Hawaii. Phytopathology 41: 769-780.

13. Carter, W. 1959. A study of mealybug populations (Dysmicoccus brevipes $(\mathrm{Ckl})$.$) in an ant-free field. Pineapple Res. Inst. Hawaii Tech. Paper$ 260:296-299.

14. Carter, W. 1963. Mealybug wilt of pineapple: A reappraisal. Ann. N.Y. Acad. Sci. 105:741-764.

15. Collins, J. L., and Carter, W. 1954. Wilt resistant mutations in the Cayenne variety of pineapple. Phytopathology 44:662-666.

16. Cudjoe, A. R., Neuenschwander, P., and Copland, M. J. W. 1993. Interference by ants in biological control of the cassava mealybug Phenacoccus manihoti (Hemiptera: Pseudococcidae) in Ghana. Bull. Entomol. Res. 83:15-22.

17. Devore, J., and Peck, R. 1986. Statistics: The Exploration and Analysis of Data. West Publishing Co., St. Paul, MN.

18. Engelbrecht, D. J., and Kasdorf, G. G. F. 1990. Transmission of grapevine leafroll disease associated closteroviruses by the vine mealybug, Planococcus ficus. Phytophylactica 22:341-346.

19. Garau, R., Prota, V. A., Boscia, D., Fiori, M., and Prota, U. 1995. Pseudococcus affinis Mask., a new vector of grapevine trichoviruses A and B. Vitis 34:67-68.

20. German, T. L., Ullman, D. E., and Gunasinghe, U. B. 1992. Mealybug wilt of pineapple. Adv. Dis. Vector Res. 9:241-259.

21. Gray, S. M. 1996. Plant virus proteins involved in natural vector transmission. Trends Microbiol. 7:259-264.

22. Gunasinghe, U. B., and German, T. L. 1986. Association of virus particles with mealybug-wilt of pineapple. (Abstr.) Phytopathology 76:1073.

23. Gunasinghe, U. B., and German, T. L. 1987. Further characterization of virus associated with mealybug-wilt of pineapple. (Abstr.) Phytopathology $77: 1776$.

24. Gunasinghe, U. B., and German, T. L. 1989. Purification and partial characterization of a virus from pineapple. Phytopathology 79:1337-1341.

25. Hu, J. S., Sether, D. M., Liu, X. P., Wang, M., Zee, F., and Ullman, D. E. 1997. Use of a tissue blotting immunoassay to examine the distribution of pineapple closterovirus in Hawaii. Plant Dis. 81:1150-1154.

26. Hu, J. S., Sether, D. M., and Ullman, D. E. 1996. Detection of pineapple closterovirus in pineapple plants and mealybugs using monoclonal antibodies. Plant Pathol. 45:829-836.

27. Illingworth, J. F. 1931. Preliminary report on evidence that mealybugs are an important factor in pineapple wilt. J. Econ. Entomol. 24:877-889.

28. Ito, K. 1938. Studies on the life history of the pineapple mealybug, Pseudococcus brevipes (Ckll.). J. Econ. Entomol. 31:291-298.

29. Jahn, G. C. 1992. The ecological significance of the big-headed ant in mealybug wilt disease of pineapple. Ph.D. thesis. University of Hawaii, Honolulu.

30. Krauss, B. H. 1948. Anatomy of the vegetative organs of the pineapple, Ananas comosus (L.) Merr. Bot. Gaz. 110:159-587.

31. La Notte, P., Buzkan, N., Choueiri, E., Minafra, A., and Martelli, G. P. 1997. Acquisition and transmission of grapevine virus A by the mealybug Pseudococcus longispinus. J. Plant Pathol. 78:79-85.

32. Lockhart, B. E. L., Autrey, L. J. C., and Comstock, J. C. 1992. Partial purification and serology of sugarcane mild mosaic virus, a mealybugtransmitted closterolike virus. Phytopathology 82:691-695.

33. Lockhart, B. E. L., Irey, M. J., and Comstock, J. C. 1996. Sugarcane bacilliform virus, sugarcane mild mosaic virus and sugarcane yellow leaf syndrome. Pages 108-112 in: Sugarcane Germplasm Conservation and Exchange: Report of an International Workshop Held in Brisbane, Queensland, Australia, 28-30 June 1995. Australian Centre for International Agricultural Research, Canberra.

34. Lockhart, B. E. L., Kiratiya-Angul, K., Jones, P., Eng, L., De Silva, P., Olszewski, N. E., Deema, N., and Sangalang, J. 1997. Identification of Piper yellow mottle virus, a mealybug-transmitted badnavirus infecting Piper spp. in southeast Asia. Eur. J. Plant Pathol. 103:303-311.

35. Lockhart, B. E. L., and Olszewski, N. E. 1996. Schefflera ringspot virus, a widely distributed mealybug-transmitted badnavirus occurring in Schefflera and Aralia. Acta Hortic. 432:196-200.

36. Milne, R. G. 1988. The filamentous plant viruses. Pages 3-50 in: The Plant Viruses, vol. 4. Plenum Press, New York.

37. Nixon, G. E. 1951. The Association of Ants with Aphids and Coccids. 
Commonwealth Institute of Entomology, London.

38. Peterson, C. L., and Charles, J. G. 1997. Transmission of grapevine leafroll associated closteroviruses by Pseudococcus longispinus and $P$. calceolariae. Plant Pathol. 46:509-515.

39. Petty, G. J., and Tustin, H. 1993. Ant (Pheidole megacephala F.)-mealybug (Dysmicoccus brevipes Ckll.) relationships in pineapples in South Africa. First International Pineapple Symposium. Acta Hortic. 334:387-395.

40. Raine, J., McMullen, R. D., and Forbes, A. R. 1986. Transmission of the agent causing little cherry disease by the apple mealybug Phenacoccus aceris and the dodder Cuscuta lupuliformis. Can. J. Plant Pathol. 8:6-11.

41. Rohrbach, K. G., and Apt, W. J. 1986. Nematode and disease problems of pineapple. Plant Dis. 70:81-87.

42. Rohrbach, K. G., Beardsley, J. W., German, T. L., Reimer, N. J., and Sanford, W. G. 1988. Mealybug wilt, mealybugs, and ants on pineapple. Plant Dis. 72:558-565.

43. Rosciglione, B., and Castellano, M. A. 1985. Further evidence that mealybugs can transmit grapevine virus A (GVA) to herbaceous hosts. Phytopathol. Mediterr. 24:186-188.

44. Rosciglione, B., Castellano, M. A., Martelli, G. P., Savino, V., and Cannizzaro, G. 1983. Mealybug transmission of grapevine virus A. Vitis
22:331-347.

45. Sether, D. M., and Hu, J. S. 1997. Transmission of pineapple closterovirus (PCV) by two species of mealybug. (Abstr.) Phytopathology (Suppl.) 87:S88.

46. Swallow, W. H. 1985. Group testing for estimating infection rates and probabilities of disease transmission. Phytopathology 75:882-889.

47. Ullman, D. E., German, T. L., Gunasinghe, U. B., and Ebesu, R. H. 1989. Serology of a closteroviruslike particle associated with mealybug wilt of pineapple. Phytopathology 79:1341-1345.

48. Wakman, W., Teakle, D. S., Thomas, J. E., and Dietzgen, R. G. 1995. Presence of a clostero-like virus and a bacilliform virus in pineapple plants in Australia. Aust. J. Agric. Res. 46:947-958.

49. Williams, D. J. 1985. Australian Mealybugs. British Museum (Natural History), London.

50. Williams, D. J., and Watson, G. W. 1988. The Scale Insects of the Tropical South Pacific Region, Part 2. The Mealybugs (Pseudococcidae). $\mathrm{CAB}$ International Institute of Entomology, London.

51. Zar, J. H. 1984. Biostatistical Analysis. Prentice-Hall, Inc., Englewood, NJ.

52. Zee, F., and Munekata, M. 1992. Biotechnology: Invitro storage of pineapple (Ananas spp.) germplasm. HortScience 27:57-58. 